\title{
THE THERAPY OF OVARIAN CYSTS IN CATTLE AND THE CHANGES IN BLOOD COUNT DURING ITS COURSE:
}

\author{
E. KUDLÁC, K. TUREČEK, J. VESELÝ, M. A. SIDDIQUI \\ Department of Obstetrics, Gynaecology and Andrology, \\ University of Veterinary and Pharmaceutical Sciences, 61242 Brno
}

Received March 31, 1992

\begin{abstract}
Kudláč E., K. Tureček, J. Veselý, and M. A. Siddiqui: The Therapy of Ovarian Cysts in Cattle and the Changes in Blood Count during its Course. Acta vet. Brno, 62, 1993: 79-88.

Synthetic hypothalamic preparations of $\mathrm{GnRH}$, produced locally, were administered in the cows of Czech Red and White breed and its crosses with Black and White cattle. There was no difference in the results after the use of DIRIGESTRAN inj. Spofa $(5 \mathrm{ml}$ and $10 \mathrm{ml}$, i. e. $200 \mu \mathrm{g}$ and $400 \mu \mathrm{g}$ of gonadorelin, respectively) and SUPERGESTRAN inj. Spofa $(4 \mathrm{ml}$, i. e. $100 \mu \mathrm{g}$ of the analogue with prolonged and stronger biological activity). The results were significantly worse with the use of lower dose of SUPERGESTRAN inj. Spofa ( $2 \mathrm{ml}$, i. e. $50 \mu \mathrm{g})$. Altogether $23.9 \%$ $(26.9 \%)$ a smaller number of cows were treated successfully $(P<0.01)$. The average age of the whole group before the treatment was 4.2 years. The average age of the successfully and unsuccessfully treated cows was 3.63 years and 5.50 years, respectively $(\mathbf{P}<0.01)$.

No statistically significant differences were found in the red blood counts before and after the treatment. Concerning the white blood count, a significant difference was found between the relative proportion of neutrophil granulocytes with segmented and non-segmented nucleus before and after the treatment $(P<0.05)$. A highly significant decrease $(P<0.01)$ in both absolute and relative numbers of lymphocytes occurred after the treatment. The successfully treated animals showed also a significant decrease of the relative percentage of monocytes $(P<0.05)$.
\end{abstract}

Cattle, syndrome of ovarian cysts, GnRH, red blood count, white blood count

The problem of ovarian cyst syndrome in cattle is being solved in veterinary medicine fordecades. Therapy has been the main point for the research, with respect to the current knowledge of etiology and availability of suitable drugs. A characteristic feature in the development of thetherapy is the gradual change from the methods of manual rupture of the cysts, evaluated by: Roberts (1955) and Dawson (1969), to the substitution therapy, based on the production of sexual hormones.

Progesterone therapy (Grandschamp 1960; Gamčík 1967; Gruss 1975) was replaced by the use of hCG, frequently in combination with progesterone (Feustel 1974; Vrtèl and Kudlác 1976; Kudláč et al. 1977 and 1980). Recently, the therapy employs usually synthetichypothalamic gonadotropin-releasing hormones and prostaglandin analogues, also in combination (Kittock et al. 1973; Grunert and Ahlers 1974; Bentele and Humke 1979; Bostedt et al. 1979; Bargai 1980; Stolla et al. 1980; Kudláč et al. 1978, 1983, 1984).

It has been demonstrated that the syndrome of ovarian cysts in cattle is influenced by hereditary factors (heritability $\mathrm{h}^{2}=0.30$ to 0.35 ). Consequently, no bulls whose dams suffered repeatedly from cysts were approved for the use in artificial insemination. However, it can be concluded after twenty years of using this rule that the occurrence of ovarian cysts under our conditions has. not decreased and remains at approximately the same level. Nevertheless, it is still necessary to include fertility in the selection criteria. High yielding dairy cows with very good fertility para-meters should be preferred (Väll 1991).

Many publications on the evaluation of the efficiency of the therapy by various drugs and by 
various therapeutic methods mentioned also the changes in genital organs and behaviour during the treatment. Recently, the study of the hormonal levels before, during and after the treatment was described by several authors (Bostedt et al. 1979; Kudláč 1988; Grunert 1991). The reliable information on the relationship between the syndrome of ovarian cysts and the blood count before and after the treatment was, however, still missing. The economical aspects of the treatment, concerning the optimum dosage and repeated administrations, are also very important. The present study deals with the above-mentioned two viewpoints of the problem.

\section{Materials and Methods}

The first part of the presented work deals with the effect of the therapeutical methods using synthetic GnRH, namely the locally produced commercial preparations DIRIGESTRAN inj. Spofa (control group), and SUPERGESTRAN inj. Spofa in the doses of $2 \mathrm{ml}$, and $4 \mathrm{ml} \mathrm{im}$., respectively, altogether in 244 cows.

DIRIGESTRAN inj. Spofa contains synthetic hypothalamic hormone gonadorelin (LHRH, $40 \mu \mathrm{g}$ in $1 \mathrm{ml}$ ). We have demonstrated previously (Ku dláč et al. 1983; Ku dlác and Pích ová 1990) that after its administration a release of LH appears. A substantial increase of LH concentrations in blood can be detected by 30 minutes and lasts for 120 to 240 minutes.

SUPERGESTRAN inj. Spofa contains $25 \mu \mathrm{g}$ of $\mathrm{GnRH}$ analogue in $1 \mathrm{ml}$. Compared to the previous preparation, the compound has a different structure of the synthetic decapeptide. Consequently, the biological effect was approximately two times stronger and was prolonged to the minimum of 240 minutes. Both preparations were administered im. to the cows of the Czech Red and White breed and its crosses with Black and White and Holstein-Friesian breeds. The age of the cows was 3 to 7 years (first to fifth lactation). The cows had clinically detected syndrome of ovarian cysts, found 60 to 90 days (exceptionally also by 120 days) after parturition. The cows were housed at the farms in the region of South Moravia, under comparable conditions of nutrition, housing, and husbandry. Their average yearly milk production was 4,000 to $5,000 \mathrm{~kg}$. Altogether 50 cows were treated with DIRIGESTRAN.inj. Spofa, and 194 cows with SUPERGESTRAN inj. Spofa (totally 244 animals). The therapeutical effect was evaluated after 10 to 14 days by a complete gynaecological examination. The fertility of the treated cows was evaluated according to the regular reproductive parameters (pregnancy rate after 1st insemination and all inseminations, insemination index, and the time period from the beginning of the treatment to the successful insemination). The results were evaluated statistically by Pearson's $\chi^{2}$ test.

The second part of the presented work consists of the study of the red and white blood cell

Table 1

The efficiency of the therapy of ovarian cysts in cows with hypothalamic GnRH (DIRIGESTRAN and SUPERGESTRAN Spofa)

\begin{tabular}{|c|c|c|c|c|c|c|c|c|c|c|c|c|}
\hline \multirow{2}{*}{$\begin{array}{c}\text { Way of } \\
\text { treatment }\end{array}$} & \multirow{2}{*}{$\begin{array}{l}\text { Num- } \\
\text { ber of } \\
\text { treated } \\
\text { cows }\end{array}$} & \multicolumn{2}{|c|}{$\begin{array}{c}\text { Successfully } \\
\text { treated after } \\
\text { first admi- } \\
\text { nistration }\end{array}$} & \multicolumn{2}{|c|}{$\begin{array}{l}\text { Suitable for } \\
\text { further } \\
\text { breeding }\end{array}$} & \multicolumn{2}{|c|}{$\begin{array}{l}\text { Pregnant } \\
\text { after 1st } \\
\text { insemina- } \\
\text { tion after } \\
\text { treatment }\end{array}$} & \multicolumn{2}{|c|}{$\begin{array}{l}\text { Total preg- } \\
\text { nancy rate }\end{array}$} & \multirow{2}{*}{$\begin{array}{l}\text { Insemi- } \\
\text { nation } \\
\text { index }\end{array}$} & \multicolumn{2}{|c|}{$\begin{array}{c}\text { Time from the } \\
\text { treatment }\end{array}$} \\
\hline & & num- & $\%$ & $\underset{\text { ber }}{\text { num- }}$ & $\%$ & $\underset{\text { ber }}{\text { num- }}$ & $\%$ & $\underset{\text { ber }}{\text { num- }}$ & $\%$ & & $\begin{array}{l}\text { to inse- } \\
\text { mination }\end{array}$ & $\begin{array}{l}\text { to success- } \\
\text { ful insemi- } \\
\text { nation }\end{array}$ \\
\hline $\begin{array}{l}\text { Dirice- } \\
\text { stran 5-10 } \\
\text { ml i.m. }\end{array}$ & 50 & 45 & 90.00 & 40 & 80.00 & 20 & 50.00 & 33 & 82.50 & 1.80 & $\begin{array}{l}27.95 \\
7-71\end{array}$ & $\begin{array}{c}39.76 \\
7-114\end{array}$ \\
\hline $\begin{array}{l}\text { Superge- } \\
\text { stran } \\
2 \mathrm{ml} \text { i.m. }\end{array}$ & 59 & 39 & 66.10 & 58 & 98.30 & 24 & 41.38 & 42 & 72.41 & 2.14 & $\begin{array}{c}23.43 \\
3-118\end{array}$ & $\begin{array}{c}46.42 \\
3-185\end{array}$ \\
\hline $\begin{array}{l}\text { Superge- } \\
\text { stran } \\
4 \mathrm{ml} \text { i.m. }\end{array}$ & 135 & 125 & 92.59 & 118 & 87.41 & 56 & 47.45 & 96 & 81.35 & 2.02 & $\begin{array}{l}23.85 \\
3-85\end{array}$ & $\begin{array}{c}46.43 \\
3-185\end{array}$ \\
\hline Total & 244 & 209 & 85.65 & 216 & 88.52 & 100 & 46.30 & 171 & 79.17 & 2.00 & $\begin{array}{l}25.08 \\
3-118\end{array}$ & $\begin{array}{c}44.20 \\
3-185\end{array}$ \\
\hline
\end{tabular}

$\chi^{2}=24.4159$

highly significant

$\chi^{2}=0.8487$

not significant

$\chi^{2}=2.2160$

not significant 
count in the cows suffering from the syndrome of ovarian cysts and the changes of these parameters after the treatment. The study was conducted in the group of 40 cows out of the conditions as mentioned above.

The diagnostics was again based on the complete gynaecological examination. In selected cases additional laboratory examinations were performed: physical examination of cervical mucus, metabolic tests, and progesterone determination.

The study was conducted in the cows with syndrome of ovarian cysts occurring 60 to 90 days (exceptionally also by 120 days) after the parturition.

Blood samples from the selected cows were collected from vena jugularis. The hormonal treatment was scheduled subsequently. During the following days the cows were monitored for the occurrence of heat. Then 21 to 25 days after the treatment the cows were again examined gynaecologically, and blood samples were again collected. Cows in heat were bred. The cows with negative palpatory finding in the ovaries, and pregnant after 1st or 2nd insemination, were considered as successfully treated.

Blood samples were collected from vena jugularis into two. test tubes with natrium citrate. Red blood cell and white blood cell counts were determined with the use of Bürker's chamber.

The white blood cells were differentiated in the panoptically stained smear. Haemoglobin was determined colorimetrically by cyanhaemoglobin method with the use of Spekol photocolorimeter (Germany). Hematocrit was evaluated after centrifugation (5 minutes at 15,250) in Wintrobe's capillaries. Sedimentation was examined in Westergreen's sedimentation instrument, adjustable to the angle of $60^{\circ}$. The other parameters of red blood cells were also calculated. Serum protein fractions were determined by electrophoresis. The results were statistically evaluated by Student's t-test.

\section{Results and Discussion}

The results of the treatment of ovarian cysts with synthetic hypothalamic GnRH preparations DIRIGESTRAN inj. Spofa and SUPERGESTRAN inj. Spofa a re summarized in Table 1 . It can be concluded that the administration of DIRIGESTRAN inj. Spofa in the doses of 5 or $10 \mathrm{ml}$ resulted in more or less the same effect as after the administration of $4 \mathrm{ml}$ of SUPERGESTRAN inj. Spofa. The results of therapy with $2 \mathrm{ml}$ of SUPERGESTRAN are worse in all evaluated parameters, and significantly worse in the percentage of successfully treated animals.

The number of animals, in which no ovarian cysts were found 10 to 15 days after the administration of $2 \mathrm{ml}$ of SUPERGESTRAN, was lower by $23.9 \%$ in comparison to the group treated with 5 and $10 \mathrm{ml}$ of DIRIGESTRAN, and by $26.9 \%$ in comparison to the group treated with $4 \mathrm{ml}$ of SUPERGESTRAN. All differences were statistically significant $\left(\chi^{2}=24.4159, \mathrm{P}<0.01\right)$.

Pregnancy rates after the 1st insemination were lower in the group of animals treated with $2 \mathrm{ml}$ of SUPERGESTRAN in comparison to the groups treated with DIRIGESTRAN (5 or $10 \mathrm{ml})$ or SUPERGESTRAN $(4 \mathrm{ml})$. The difference was $8.62 \%$ and $6.07 \%$, respectively. This result was not statistically significant, however, it should be considered that the number of animals was low. Similar results were obtained in the evaluation of pregnancy rates after all inseminations. Lower pregnancy rates were obtained in the group treated with $2 \mathrm{ml}$ of SUPERGESTRAN inj. Spofa but the differences were not statistically significant.

The time period from the first treatment until the insemination was practically the same in all groups, as well as the time period until the successful insemination. It can be concluded that the average time of 44.2 days required for getting the cow pregnant is economically feasible, and the described therapy schedule can be recommended.

Stolla et al. (1980) studies also the therapeutical effect with the use of different preparations. The authors achieved $60 \%$ pregnancy rate after the treatment of ovarian cysts with RECEPTAL Hoechst (dose of $10 \mu \mathrm{g} \mathrm{GnRH}$ ), and $65 \%$ preg- 
nancy rate with the dose of $20 \mu \mathrm{g}$. The differences were not statistically significant. Our results correspond with the findings of Bargai (1982), who obtained the following results in the animals treated with oil solution of $\mathrm{LH}$ and without the manual rupture of the cysts: 46.4 days from the treatment to the successful insemination, $65 \%$ of successfully treated animals, totally $47 \%$ pregnant animals). In our previous works (Kudláč 1984) we obtained with LUTAL Hoechst $70 \%$ success rate in the treatment of ovarian cysts and total pregnancy rate over $80 \%$ on average in 45 days after the treatment. The comparison demonstrates the similar results of therapy. Some differences in the results might originate from the different fertility of the experimental groups housed under various conditions.

We attempted to determine the relation between the age of the cows at the treatment and the resulting effect. The average age of the cows before the treatment was 4.2 years. We have found that the successful treatment was achieved in the group of animals of the average age of 3.63 years. The age of the animals that were treated unsuccessfully averaged 5.50 years. The difference was statistically significant $(P<0.01)$.

Similar results were obtained in the evaluation of the group of cows according to the number of previous calvings. The overall average in the group was 2.076 previous calvings, with the average of 1.630 in successfully treated and 3.083 in unsuccessfully treated animals. The differences were significant between the whole group and the successfully treated group $(P<0.05)$ and highly significant between the successfully and unsuccessfully treated group $(P<0.01$; Student's t-test).

Many authors studied the age and the number of previous calvings in the cows suffering from the syndrome of ovarian cysts, with regard to the relation to the gradually increasing milk production with the peak between 4th and 7th year of age (2nd to 5th lactation). Kudláč et al. (1984) and Bargai (1982) mentioned that the syndrome of ovarian cysts occurred in $70 \%$ of the cases in the cows until 5 years of age. Bostedt et al. (1980) found that $33.6 \%$ of the cases of ovarian cysts occurred in cows at the age of 2 to 4 years. We have found no data in the available sources on the evaluation of the relation of the age of the cows suffering from ovarian cysts and the therapeutical effect. It can be therefore concluded from our results that the therapy with GnRH has better prognosis in the younger animals with better adaptation possibilities that have to be always considered under the conditions of large-scale farms.

Table 2

The efficiency of the therapy of ovarian cysts in cows with regard to age and number of previous calvings

\begin{tabular}{|c|c|c|c|c|c|}
\hline \multirow{2}{*}{ Group } & \multirow[b]{2}{*}{$\begin{array}{l}\text { Num- } \\
\text { ber of } \\
\text { animals }\end{array}$} & \multicolumn{2}{|c|}{ Age of cows in years } & \multicolumn{2}{|c|}{ Number of previous calvings } \\
\hline & & Average-range & $\begin{array}{c}\text { statistical evaluation } \\
\text { by } \mathrm{T} \text { test }\end{array}$ & average-range & $\begin{array}{c}\text { statistical evaluation } \\
\text { by } T \text { test }\end{array}$ \\
\hline $\begin{array}{l}\text { Before } \\
\text { treatment }\end{array}$ & 40 & $\begin{array}{l}4.20 \\
3-7\end{array}$ & $\begin{array}{c}t_{1.2}=1.82150 \\
\text { not significant }\end{array}$ & $\begin{array}{r}2.076 \\
1-5\end{array}$ & $\begin{array}{r}t_{1 \cdot 2}=0.75418 \\
\text { not significant }\end{array}$ \\
\hline $\begin{array}{l}\stackrel{2 .}{\text { Successfully }} \\
\text { treated }\end{array}$ & 28 & $\begin{array}{l}3.63 \\
3-6\end{array}$ & $\begin{array}{c}\mathrm{t}_{1.2}=2.73075 \\
\mathbf{P}<0.01 \\
\text { highly significant }\end{array}$ & $\begin{array}{r}1,630 \\
1-4\end{array}$ & $\begin{array}{c}t_{1 \cdot 2}=1.96019 \\
P<0.05 \\
\text { significant }\end{array}$ \\
\hline $\begin{array}{l}\text { Unsiccessfully } \\
\text { treated }\end{array}$ & 12 & $\begin{array}{l}5.50 \\
3-7\end{array}$ & $\begin{array}{c}t_{1.2}=4.84806 \\
P<0.01 \\
\text { highly significant }\end{array}$ & $\begin{array}{ll}3.083 \\
\quad 1-5\end{array}$ & $\begin{array}{c}t_{1 \cdot 2}=4.11837 \\
P<0.01 \\
\text { highly significant }\end{array}$ \\
\hline
\end{tabular}


Table 3a

Statistical significance of the differences in red blood cell count in cows with ovarian cysts before and after the treatment

\begin{tabular}{|c|c|c|c|c|c|c|c|}
\hline \multirow[b]{2}{*}{ Group } & \multirow[b]{2}{*}{$\begin{array}{l}\text { Num- } \\
\text { ber of } \\
\text { animals }\end{array}$} & \multicolumn{2}{|c|}{ Red blood cells $\times 10^{6}$} & \multicolumn{2}{|c|}{ Haemoglobin (g \%) } & \multicolumn{2}{|c|}{ Haematocrit (\%) } \\
\hline & & $\begin{array}{l}\text { Average - } \\
\text { range }\end{array}$ & $\begin{array}{l}\text { statistical } \\
\text { evaluation } \\
\text { b T test }\end{array}$ & $\begin{array}{l}\text { Average - } \\
\text { range }\end{array}$ & $\begin{array}{r}\text { statistical } \\
\text { evaluation } \\
\text { by } T \text { test }\end{array}$ & $\begin{array}{l}\text { Average - } \\
\text { range }\end{array}$ & $\begin{array}{c}\text { statistical } \\
\text { evaluation } \\
\text { by } T \text { test }\end{array}$ \\
\hline $\begin{array}{l}1 . \\
\text { Before } \\
\text { treatment }\end{array}$ & 40 & $\begin{array}{c}7.34 \\
6.13-8.7\end{array}$ & $\begin{array}{l}t_{1 \cdot 2}=0.31082 \\
\text { not significant }\end{array}$ & $\begin{array}{c}10.52 \\
9.7-11.4\end{array}$ & $\begin{array}{l}t_{1 \cdot 2}=0.45599 \\
\text { not significant }\end{array}$ & $\begin{array}{c}38.12 \\
29.1-48.1\end{array}$ & $\begin{array}{l}t_{1 \cdot 2}=0.38415 \\
\text { not significant }\end{array}$ \\
\hline \begin{tabular}{l}
\multicolumn{1}{c}{2.} \\
Success \\
fully \\
treatment
\end{tabular} & 28 & $\begin{array}{c}7.40 \\
5.7-8.6\end{array}$ & $\begin{array}{l}t_{1 \cdot 3}=0.95826 \\
\text { not significant }\end{array}$ & $\begin{array}{c}10.57 \\
9.8-11.4\end{array}$ & $\begin{array}{l}t_{1 \cdot 3}=0.68165 \\
\text { not significant }\end{array}$ & $\begin{array}{c}38.42 \\
33.5-47.8\end{array}$ & $\begin{array}{l}t_{1 \cdot 3}=0.11490 \\
\text { not significant }\end{array}$ \\
\hline $\begin{array}{l}\quad 3 . \\
\text { Unsuc- } \\
\text { cessfully } \\
\text { treatment }\end{array}$ & 12 & $\begin{array}{c}7.10 \\
6.2-8.2\end{array}$ & $\begin{array}{l}\mathrm{t}_{2 \cdot 3}=1.13816 \\
\text { not significant }\end{array}$ & $\begin{array}{c}10.41 \\
9.6-10.9\end{array}$ & $\begin{array}{l}t_{2 \cdot 3}=1.08508 \\
\text { not significant }\end{array}$ & $\begin{array}{c}38.00 \\
34.7-41.0\end{array}$ & $\begin{array}{c}t_{2 \cdot 3}=0.496892 \\
\text { not significant }\end{array}$ \\
\hline
\end{tabular}

Table 3b

Statistical significance of the differences in red blood cell count in cows with ovarian cysts before and after the treatment

\begin{tabular}{|c|c|c|c|c|c|c|c|}
\hline \multirow[b]{2}{*}{ Group } & \multirow{2}{*}{$\begin{array}{l}\text { Num- } \\
\text { ber of } \\
\text { animals }\end{array}$} & \multicolumn{2}{|c|}{ Sedimentation after 1 hour } & \multicolumn{2}{|c|}{ Sedimentation after 2 hours } & \multicolumn{2}{|c|}{ Sedimentation after 24 hours } \\
\hline & & $\begin{array}{l}\text { Average - } \\
\text { range }\end{array}$ & $\begin{array}{l}\text { statistical } \\
\text { evaluation } \\
\text { by } T \text { test }\end{array}$ & $\begin{array}{l}\text { Average - } \\
\text { range }\end{array}$ & $\begin{array}{l}\text { statistical } \\
\text { evaluation } \\
\text { by } T \text { test }\end{array}$ & $\begin{array}{l}\text { Average - } \\
\text { range }\end{array}$ & $\begin{array}{c}\text { statistical } \\
\text { evaluation } \\
\text { by } T \text { test }\end{array}$ \\
\hline $\begin{array}{l}1 . \\
\text { Before } \\
\text { treatment }\end{array}$ & 40 & $\begin{array}{c}1.012 \\
0.5-3.0\end{array}$ & $\begin{array}{l}t_{1.2}=0.42476 \\
\text { not significant }\end{array}$ & $\begin{array}{c}2.150 \\
1.0-5.2\end{array}$ & $\begin{array}{l}t_{1 \cdot 2}=0.21608 \\
\text { not significant }\end{array}$ & $\begin{array}{c}7.325 \\
2.0-9.0\end{array}$ & $\begin{array}{l}\mathrm{t}_{1.2}=1.15182 \\
\text { not significant }\end{array}$ \\
\hline $\begin{array}{l}\text { 2. } \\
\text { Success- } \\
\text { fully } \\
\text { treatment }\end{array}$ & 28 & $\begin{array}{c}1.071 \\
0.5-3.0\end{array}$ & $\begin{array}{l}t_{1 \cdot 3}=0.37515 \\
\text { not significant }\end{array}$ & $\begin{array}{c}2.210 \\
1.0-7.0\end{array}$ & $\begin{array}{l}t_{1 \cdot 3}=1.30518 \\
\text { not significant }\end{array}$ & $\begin{array}{c}7.750 \\
2.0-10.0\end{array}$ & $\begin{array}{l}\mathbf{t}_{1 \cdot 3}=0.38829 \\
\text { not significant }\end{array}$ \\
\hline $\begin{array}{l}\quad 3 . \\
\text { Unsuc- } \\
\text { cessfully } \\
\text { treatment }\end{array}$ & 12 & $0.5-1.0$ & $\begin{array}{l}t_{2 \cdot 3}=0.48206 \\
\text { not significant }\end{array}$ & 1.750 & $\begin{array}{l}t_{2 \cdot 3}=1.64462 \\
\text { not significant }\end{array}$ & $6.0-9.0$ & $\begin{array}{l}t_{2 \cdot 3}=0.49859 \\
\text { not significant }\end{array}$ \\
\hline
\end{tabular}

Table 3c

Statistical significance of the differences in red blood cell count in cows with ovarian cysts before and after the treatment

\begin{tabular}{|c|c|c|c|c|c|c|c|}
\hline \multirow{2}{*}{ Group } & \multirow{2}{*}{$\begin{array}{l}\text { Num- } \\
\text { ber of } \\
\text { animals }\end{array}$} & \multicolumn{2}{|c|}{$\begin{array}{l}\text { Mean cellular volume of } \\
\text { erythrocytes (MCV) }\end{array}$} & \multicolumn{2}{|c|}{$\begin{array}{l}\text { Mean cellular haemoglobin } \\
(\mathrm{MCH})\end{array}$} & \multicolumn{2}{|c|}{$\begin{array}{l}\text { Mean cellular haemoglobin } \\
\text { concentration (MCHC) }\end{array}$} \\
\hline & & $\begin{array}{l}\text { Average - } \\
\text { range }\end{array}$ & $\begin{array}{l}\text { statistical } \\
\text { evaluation } \\
\text { by } T \text { test }\end{array}$ & $\begin{array}{c}\text { Average - } \\
\text { range }\end{array}$ & $\begin{array}{l}\text { statistical } \\
\text { evaluation } \\
\text { by } T \text { test }\end{array}$ & $\begin{array}{l}\text { Average - } \\
\text { range }\end{array}$ & $\begin{array}{l}\text { statistical } \\
\text { evaluation } \\
\text { by T test }\end{array}$ \\
\hline $\begin{array}{l}1 . \\
\text { Before } \\
\text { treatment }\end{array}$ & 40 & $\begin{array}{c}52.615 \\
45.4-75.3\end{array}$ & $\begin{array}{l}t_{1 \cdot 2}=0.08660 \\
\text { not significant }\end{array}$ & $\begin{array}{c}14.407 \\
13.0-16.8\end{array}$ & $\begin{array}{l}t_{1 \cdot 2}=0.39441 \\
\text { not significant }\end{array}$ & $\begin{array}{c}27.150 \\
20.7-30.3\end{array}$ & $\begin{array}{l}t_{1 \cdot 2}=0.12516 \\
\text { not significant }\end{array}$ \\
\hline \begin{tabular}{l}
\multicolumn{1}{c}{2.} \\
Success- \\
fully \\
treatment
\end{tabular} & 28 & $\begin{array}{c}52.464 \\
45.5-73.5\end{array}$ & $\begin{array}{l}\mathrm{t}_{1 \cdot 3}=0.57894 \\
\text { not significant }\end{array}$ & $\begin{array}{c}14.330 \\
13.0-15.8\end{array}$ & $\begin{array}{l}t_{1 \cdot 3}=0.52812 \\
\text { not significant }\end{array}$ & $\begin{array}{r}27.207 \\
20.8-30.1\end{array}$ & $\begin{array}{c}\mathrm{t}_{1.3}=0.41102 \\
\text { not significant }\end{array}$ \\
\hline $\begin{array}{l}\quad 3 . \\
\text { Unsuc- } \\
\text { cessfully } \\
\text { treatment }\end{array}$ & 12 & $\begin{array}{c}53.933 \\
47.4-63.8\end{array}$ & $\begin{array}{l}t_{2 \cdot 3}=0.63277 \\
\text { not singificant }\end{array}$ & $\begin{array}{c}14.740 \\
13.04-16.9\end{array}$ & $\begin{array}{l}t_{2 \cdot 3}=0.69445 \\
\text { not significant }\end{array}$ & $\begin{array}{c}26.891 \\
20.5-29.1\end{array}$ & $\begin{array}{l}t_{2 \cdot 3}=0.52358 \\
\text { not singificant }\end{array}$ \\
\hline
\end{tabular}


Concerning red blood cell count there were no statistically significant differences (Tab. 3a to 3c) among the groups of animals before the treatment, successfully and unsuccessfully treated.

Concerning white blood cell count there were no statistically significant differences between the numbers of white blood cells in the animals before the treatment and the groups of animals treated both successfully and unsuccessfully (Tab. 4a).

The percentage of neutrophil granulocytes with segmented nucleus differed in the animals before the treatment and after the treatment, regardless to the result of the therapy. The difference between the animals before the treatment and the successfully treated animals was statistically significant (32.700 and 35.857; $P<0.05)$. The difference between the animals before the treatment and treated unsuccessfully (32.700 and 35.865) was not much distinct but not statistically significant, probably because of the small number in the group of unsuccessfully treated animals.

A similar pattern was found also in the case of neutrophil granulocytes with non-segmented nucleus. There was also an increase of the numbers of this type of white blood cells after the treatment, regardless to its result. The statistical evaluation was similar as previously, i. e. significant difference between the groups before the treatment and successfully treated $(4,106$ and 5,$112 ; \mathrm{P}<0.05)$ and a similar but not significant difference between the groups before the treatment and unsuccessfully treated $(4,106$ and 5,016). It can be assumed that the low number of unsuccessfully treated animals should be taken into account also in this case.

The relative content of lymphocytes (Tab. $4 \mathrm{~b}$ ) changed markedly only in successfully treated cows $(54,042$ vs. 48,511$)$. The decrease was statistically highly significant $(P<0.01)$. The difference between the groups of animals before the treatment and unsuccessfully treated $(54,042$ and 51,853$)$ was statistically not significant. In the absolute numbers of lymphocytes the difference was 4,179 vs. 4,088 (before the treatment vs. unsuccessfully treated; the difference of more than $2 \%$ in the relative counts originated only from the calculation scheme).

Table 4a

Statistical significance of the difierences in white blood cell count in cows with ovarian cysts before and after the treatment

\begin{tabular}{|c|c|c|c|c|c|c|c|}
\hline \multirow{2}{*}{ Group } & \multirow{2}{*}{$\begin{array}{l}\text { Num- } \\
\text { ber of } \\
\text { animals }\end{array}$} & \multicolumn{2}{|c|}{$\begin{array}{l}\text { Number of leukocytes } \times 10^{2} \\
\text { in } \mathrm{mm}\end{array}$} & \multicolumn{2}{|c|}{$\begin{array}{l}\text { Neutrophil granulocytes } \\
\text { with segmented nucleus (\%) }\end{array}$} & \multicolumn{2}{|c|}{$\begin{array}{l}\text { Neutrophil granulocytes with } \\
\text { non-segmented nucleus (\%) }\end{array}$} \\
\hline & & $\begin{array}{l}\text { Average - } \\
\text { range }\end{array}$ & $\begin{array}{l}\text { statistical } \\
\text { evaluation } \\
\text { by } T \text { test }\end{array}$ & $\begin{array}{l}\text { Average - } \\
\text { range }\end{array}$ & $\begin{array}{l}\text { statistical } \\
\text { evaluation } \\
\text { by } T \text { test }\end{array}$ & $\begin{array}{l}\text { Average - } \\
\text { range }\end{array}$ & $\begin{array}{l}\text { statistical } \\
\text { evaluation } \\
\text { by } T \text { test }\end{array}$ \\
\hline $\begin{array}{l}1 . \\
\text { Before } \\
\text { treatment }\end{array}$ & 40 & $\begin{array}{c}7.734 \\
7.1-8.9\end{array}$ & $\begin{array}{l}t_{1 \cdot 2}=0.08874 \\
\text { not significant }\end{array}$ & $\begin{array}{c}32.700 \\
13.5-42.4\end{array}$ & $\begin{array}{c}t_{1 \cdot 2}=2.17259 \\
\text { significant }\end{array}$ & $\begin{array}{c}4.106 \\
2.1-6.5\end{array}$ & $\begin{array}{c}t_{1 \cdot 2}=3.28683 \\
\text { highly significant }\end{array}$ \\
\hline $\begin{array}{l}\text { S. } \\
\text { Success- } \\
\text { fully } \\
\text { treatment }\end{array}$ & 28 & $\begin{array}{c}7.724 \\
6.2-8.6\end{array}$ & $\begin{array}{l}t_{1 \cdot 3}=0.91270 \\
\text { not significant }\end{array}$ & $\begin{array}{c}35.587 \\
22.6-46.6\end{array}$ & $\begin{array}{c}P<0.01 \\
t_{1 \cdot 3}=1.55251 \\
\text { not significant }\end{array}$ & $\begin{array}{c}5.117 \\
1.6-8.5\end{array}$ & $\begin{array}{c}P<0.01 \\
t_{1 \cdot 3}=2.33307 \\
\text { significant } \\
P<0.05\end{array}$ \\
\hline $\begin{array}{l}\quad 3 . \\
\text { Unsuc- } \\
\text { cessfully } \\
\text { treatment }\end{array}$ & 12 & $\begin{array}{c}7.884 \\
7.2-8.89\end{array}$ & $\begin{array}{l}t_{2 \cdot 3}=0.91774 \\
\text { not significant }\end{array}$ & $\begin{array}{c}35.865 \\
24.5-43.5\end{array}$ & $\begin{array}{l}t_{2 \cdot 8}=0.00391 \\
\text { not significant }\end{array}$ & $\begin{array}{c}5.016 \\
1.5-6.6\end{array}$ & $\begin{array}{c}t_{2 \cdot 3}=0.20238 \\
\text { not significant }\end{array}$ \\
\hline
\end{tabular}


Table $4 \mathrm{~b}$

Statistical significance of the differences in white blood cell count in cows with ovarian cysts before and after the treatment

\begin{tabular}{|c|c|c|c|c|c|c|c|}
\hline \multirow{2}{*}{ Group } & \multirow{2}{*}{$\begin{array}{l}\text { Num- } \\
\text { ber of } \\
\text { animals }\end{array}$} & \multicolumn{2}{|c|}{$\begin{array}{l}\text { Lymfocytes (large and small) } \\
\text { in } \%\end{array}$} & \multicolumn{2}{|c|}{ Monocytes in \% } & \multicolumn{2}{|c|}{ Basophil granulocytes in \% } \\
\hline & & $\begin{array}{l}\text { Average - } \\
\text { range }\end{array}$ & $\begin{array}{l}\text { statistical } \\
\text { evaluation } \\
\text { by } T \text { test }\end{array}$ & $\begin{array}{l}\text { Average - } \\
\text { range }\end{array}$ & $\begin{array}{l}\text { statistical } \\
\text { evaluation } \\
\text { by } T \text { test }\end{array}$ & $\begin{array}{l}\text { Average - } \\
\text { range }\end{array}$ & $\begin{array}{c}\text { statistical } \\
\text { evaluation } \\
\text { by } T \text { test }\end{array}$ \\
\hline $\begin{array}{l}\text { Before } \\
\text { treatment }\end{array}$ & 40 & $\begin{array}{c}54.042 \\
40.1-72.0\end{array}$ & $\begin{array}{c}t_{1.2}=3.18726 \\
\text { highly significant } \\
P<0.01\end{array}$ & $\begin{array}{c}4.589 \\
2.1-7.8\end{array}$ & $\begin{array}{c}t_{1 \cdot 2}=2.24980 \\
\text { significant } \\
P<0.05\end{array}$ & $\begin{array}{c}0.243 \\
0.1-0.6\end{array}$ & $\begin{array}{l}t_{1 \cdot 2}=0.41520 \\
\text { not significant }\end{array}$ \\
\hline $\begin{array}{l}\text { 2. } \\
\text { Success- } \\
\text { fully } \\
\text { treatment }\end{array}$ & 28 & $\begin{array}{c}48.511 \\
40.1-62.4\end{array}$ & $\begin{array}{l}t_{1 \cdot 3}=0.83738 \\
\text { not significant }\end{array}$ & $\begin{array}{c}4.024 \\
2.8-5.7\end{array}$ & $\begin{array}{l}t_{1 \cdot 3}=1.00969 \\
\text { not significant }\end{array}$ & $\begin{array}{r}0.256 \\
0.1-0.5\end{array}$ & $\begin{array}{l}t_{1 \cdot 3}=0.31098 \\
\text { not significant }\end{array}$ \\
\hline $\begin{array}{l}\quad 3 . \\
\text { Unsuc- } \\
\text { cessfully } \\
\text { treatment }\end{array}$ & 12 & $\begin{array}{c}51.853 \\
38.6-62.4\end{array}$ & $\begin{array}{l}t_{2.3}=1.52510 \\
\text { not significant }\end{array}$ & $\begin{array}{c}4.203 \\
2.1-6.2\end{array}$ & $\begin{array}{l}t_{2 \cdot 3}=0.57902 \\
\text { not significant }\end{array}$ & $\begin{array}{c}0.260 \\
0.1-0.6\end{array}$ & $\begin{array}{l}t_{2 \cdot 3}=0.05333 \\
\text { not significant }\end{array}$ \\
\hline
\end{tabular}

Table 4c

Statistical significance of the differences in white blood cell count in cows with ovarian cysts before and after the treatment

\begin{tabular}{|c|c|c|c|c|c|}
\hline \multirow[b]{2}{*}{ Group } & \multirow{2}{*}{$\begin{array}{c}\text { Number of } \\
\text { animals }\end{array}$} & \multicolumn{2}{|c|}{ Eosinophil granulocytes in \% } & \multicolumn{2}{|c|}{ Albumin/globulin ratio } \\
\hline & & $\begin{array}{l}\text { Average - } \\
\text { range }\end{array}$ & $\begin{array}{c}\text { statistical evaluation } \\
\text { by } T \text { test }\end{array}$ & Average - range & $\begin{array}{c}\text { statistical evaluation } \\
\text { by } T \text { test }\end{array}$ \\
\hline $\begin{array}{l}\text { Before } \\
\text { treatment }\end{array}$ & 40 & $\begin{array}{c}4.965 \\
1.5-9,1\end{array}$ & $\begin{array}{l}t_{1.2}=1.88881 \\
\text { not significant }\end{array}$ & $\begin{array}{c}0.627 \\
0.58-0.69\end{array}$ & $\begin{array}{l}t_{1.2}=0.52394 \\
\text { not significant }\end{array}$ \\
\hline $\begin{array}{l}2 . \\
\text { Successfully } \\
\text { treatment }\end{array}$ & 28 & $\begin{array}{c}4.241 \\
1.3-6.6\end{array}$ & $\begin{array}{l}t_{1 \cdot 3}=1.58885 \\
\text { not significant }\end{array}$ & $\begin{array}{c}0.630 \\
0.61-0.68\end{array}$ & $\begin{array}{l}t_{1.3}=0.55603 \\
\text { not significant }\end{array}$ \\
\hline $\begin{array}{l}\quad 3 . \\
\text { Unsuccessfully } \\
\text { treatment }\end{array}$ & 12 & $\begin{array}{c}4.104 \\
1.3-5.7\end{array}$ & $\begin{array}{l}t_{2 \cdot 3}=0.30284 \\
\text { not significant }\end{array}$ & $\begin{array}{c}0.632 \\
0.59-0.68\end{array}$ & $\begin{array}{l}t_{2 \cdot 3}=0.24833 \\
\text { not significant }\end{array}$ \\
\hline
\end{tabular}

The absolute lymphocyte count in successfully treated cows was 3,747 , i. e. markedly lower than before the treatment.

Another statistically significant decrease was found in the case of the relative content of monocytes (before and after the treatment $-4,589$ vs. 4,$024 ;(P<$ $<0.05$ ). The difference between the cows before the treatment and unsuccessfully treated (4,589 and 4,203) was not statistically significant.

There were no statistically significant differences in the relative content of basophil granulocytes and eosinophil granulocytes (Tab. 4c). The albumin/globulin ratio in blood serum has not changed significantly as well.

The authors that had studied the changes of white blood cell count during the postparturient period (Moberg 1956; Kudláč and Benýšek 1971; Stodola et al. 1984) mentioned the decrease of the absolute leukocyte count in the early phase, i. e. until 14 days post partum. The changes are apparently connected with the involution of the uterus and the recovery of the organism after 
the pregnancy. We mentioned in our previous works a possible connection between the changes of white blood cell count and primary disorders of genital organs, and the changes in hormone levels. In this work we attempted to study the relation between the syndrome of ovarian cysts and blood cell counts. We recorded the increase of the relative number of neutrophil granulocytes with segmented and non-segmented nucleus in treated animals. However, no clear relation to the result of the treatment was established. Although we did not determine the levels of gonadal hormones in blood, it can be supposed that in successfully treated cows the influence of progesterone prevailed. It seems that the hormonal imbalance has no reflection in white blood cell count, namely in the relative proportion of separate types of leukocytes. The influence of other environmental factors, or stress situations at blood sampling, cannot be completely ruled out.

A significant decrease of lymphocyte numbers occurred in treated cows, both in relative and absolute numbers. The difference is clear when the group of animals before the treatment was compared also to the unsuccessfully treated cows. This finding corresponds to undoubtedly decreased level of oestrogens in blood that appears after the ovarian cysts have disappeared.

It was impossible to compare our results to the results of other authors, as we have not found similar studies. It is desirable to continue in similar studies with the determination of hormone levels of the cows with ovarian cysts before and after the treatment with regard to its results.

\section{Léčba ovariálních cyst u skotu a morfologické změny krevního obrazu $v$ jejím prủběhu}

U krav českého červenostrakatého plemene a jeho kříženek s černostrakatým nížinným byly aplikovány syntetické hypotalamické $\mathrm{GnRH}$ v preparátech česko\$lovenské provenience. Při aplikaci přípravku DIRIGESTRAN inj. Spofa v dávce 5 a $10 \mathrm{ml}$, tj. 200 a $400 \mu$ g gonadorelinu a SUPERGESTRAN inj. Spofa v dávce $4 \mathrm{ml}$, tj. $40 \mu \mathrm{g}$ analogu s protrahovanou a vyšší biologickou účinností se výsledky nelišily. Př̀i aplikaci SUPERGESTRANU inj. Spofa v dávce $2 \mathrm{ml}$ byly výsledky průkazně horší, bylo vyléčeno o $23,9 \%$, resp. $26,9 \% \mathrm{krav}$ méně $(\mathrm{P}<0,01)$. Prưměrný věk celého souboru před léčbou byl 4,2 roku, vyléčených 3,63 roku, nevyléčených 5,50 roku $(P<0,01)$.

Nebyly zjištěny statisticky významné rozdily mezi hodnotami červeného krevního obrazu krav před zahájením a po skončení léčby. V bílém krevním obraze se zjistil statisticky významný rozdíl mezi relativním podilem neutrofilních granulocytů se segmentovaným a tyčkovitým jádrem před léčbou a po léčbě $(\mathbf{P}<$ $<0,05)$. U lymfocytů došlo po léčbě $\mathrm{k}$ statisticky vysoce významnému poklesu relativního $\mathrm{i}$ absolutního počtu $(\mathrm{P}<0,01)$. U vyléčených zviŕat došlo též $\mathrm{k}$ statisticky významnému poklesu relativního podílu monocytů $(P<0,05)$.

\section{Лечение овариальных кист крупного рогатого скота} и морфологические изменения картины крови в ходе их протекания

У коров чешской красно-пестрой породы и ее помесями с черно-пестрой низменной породой применяли синтетические гипоталамические $\mathrm{GnRH}$ в препаратах чехословацкого происхождения. При при- 
менении препарата ДИРИГЕСТРАН в уколах Спофа дозой 5 и 10 мл, следовательно, 200 и 400 мкг гонадерелина и препарата СУПЕР. ГЕСТРАН в уколах Спофа дозой 4 мл, т. е. 40 мкг аналога с протрагированным и более эффективным воздействием, результаты не расХодились. При применении СУПЕРГЕСТРАНА в үколах Спофа дозой 2 мл результаты получались явно хүже. Исцелили на 23,9 \% или 26,9 процента коров меньше $(P<0,01)$. Средний возраст комплекса в целом до лечения достигал 4,2 года, изцеленных - 3,63 года, неизлечимых - 5,50 года $(P<0,01)$.

Не была выявлена статистически значимая разница между величинами картин красной крови до начала и по окончании лечения. В картине белой крови была установлена статистически значимая разница между относительной долей нейстрофильных гранулоцитов с сегментированными и палочным ядром до и после лечения $(P<0,05)$. У лимфоцитов после лечения установили статистически весьме значимое понижение относительной и абсолютной численности $(P<0,01)$. У исцеленных животных было установлено также статистически значимое понижение относительной доли моноцитов $(\mathrm{P}<0,05)$.

\section{References}

BENTELE, W.-HUMKE, R.: Zur Therapie der Ovarialzysten des Rindes mit LH-FSH-Releasinghormonen. Tierärztl. Umsch., 34, 1979: 779-791

BARGAI, U.: Deset let výzkumu ovariálních cyst u krav v intenzívním chovu. Proceedings of the XIIth World Congress on Diseases of Cattle, Amsterdam, 1982: p. 601

BOSTEDT, H.-STOLLA, R.-HUNDSCHEL, C.-LEIDL, W.: Zur Ovarialzyste des Rindes, III. vergleichende Wertung von Therapieverfahren. Berl. Münch. T. Wchschr., 92, 1979: $506-511$

DAWSON, F. L. M.: Die Therapie der Eierstockzysten beim Rind. Proceedings of the 19. mezinár. konf. Wels 1969

FEUSTEL, G.: Beitrag zur Behandlung der Ovarialzysten beim Rind mit HCG suspendiert in öligem Progesteron. Tierärztl. Umsch., 30, 1975: 515-516

GAMCIIK, P.: Terapeutické použitie ovariálnych hormonov pri funkčných poruchách plodnosti kráv a jalovíc. Veterinaria, Spofa, 9, 1967: 157-162

GRANDSCHAMP, G.: Les indications et le mode d'emploi de la progesterone chez la vache. Schw. A. Tierheilk., 102, 1960: 18-24

GRUNERT, E.-AHLERS, D.: Die Therapie der Eierstockzysten beim Rind aus kritischer Sicht. Vet. Med. Nachr., 1974: 386-388

GRUSS, V.: Behandlungsergebnisse bei Ovarialzysten des Rindes nach Applikation von Choroingonadotropin und/oder verabreichtem Gestagen in Kombination mit Vitaminen. Tierärztl. Umsch., 30, 1975: 605-609

KITTOCK, R. J. - BRITT, J. H. -CONVEY, E. M.: Endocrine response after GnRH in luteal phase cows and cows with ovarian follicular cysts. J. Anim. Sci., 37, 1973: 985-989

KUDLÁC, E. - VRTĚL, M.: Účinnost intravenózní a intraperitoneální aplikace HCG (Praedyn Spofa) v kombinaci s progesteronem (Agolutin depot Spofa) při syndromu ovariálních cyst u skotu. Veterinaria Spofa, XIX, 1977: 5-24

KUDLÁC̆, E.-VRTĚL, M.: Léčba syndromu cystózní degenerace ovarií u skotu syntetickým GnRH (Lutal). Vet. med. (Praha), 23, 1978: 401-409

KUDLÁC, E.: Fyziologie a patologie puerperia a ovlivňování repordukčních funkcí v postpartálním období u krav a prasnic. DrSc. Thesis, VŠV Brno, 1988: $141-142$

KUDLÁČ, E. - VINKLER; A.-VLČEK, Z.-VRTĚL, M.: Terapie syndromu ovariálních cyst novým prýipravkem Praedyn compositum (Spofa) Biol. Chem. Vet., Praha, 16, 1980: $167-174$

KUDLÁC, E.-BENÝŠEK, V.: Dynamics of changes in white blood cell count of cows during puerperium. Acta vet. Brno, 40, 1971: $345-352$

KUDLÁČ, E. - VLČEK, Z. - VRTĚL, M. - VINKLER, A.-NEDBÁLKOVÁ, J. - VÁCLAVÍK, F.: Terapie syndromu ovariálních cyst u skotu Dirigestranem inj. Spofa (syntetický GnRH). Biol. Chem. Vet., 19, 1983: 125-138 
KUDLÁČ, E.-VRTĚL, M.-VLCEK, Z.-VINKLER, A.-VÁCLAVfK, F.: Terapeutický efekt Oestrophanu (syntetický analog $\mathrm{PGF}_{2}$ alfa-cloprostenol) při některých poruchách plodnosti u skotu. Biol. Chem. Vet., Praha, 20, 1984: 359-370

KUDLÁC, E.-PfCHOVÁ, D.: Responze adenohypofysy a účinnost aplikace syntetického GnRH (Dirigestran inj. Spofa) u krav post partum. Vet. Med., Praha, 35, 1990: 321-330

MOBERG, K.: The white blood picture during parturition in cows with special reference to retained foetal membranes. Proc. of 3rd Intern. Congr. on Anim. Reproduction, Cambridge, 1956: $58-60$

ROBERTS, S. J.: Clinical observations on cystic ovaries in dairy cattle. Cornell Vet., 45, 1955 : 497-513

STODOLA, J.-SLIPKA, J.-KEHOUT, V.: Vliv porodu na hladinu krevních ukazovatelů u dojnic. Sb. VSZZ v Praze, PEF v C. Budějovicích, R. zootech., 1984: 89-101

STOLLA, R. - BOSTEDT, H. - WENDT, V.-LEIDL, W.: Zur Ovarialzyste des Rindes, II. vergleichende Wertung von Therapieverfahren Berl. Münch. Tierärztl. Wchschr., 93, 1970: 4-10

VÖLL, S.: Hohe Milchleistung und gute Fruchtbarkeit - ein Wiederspruch? Dtsch. Schwarzbunte, 15, 1991: 16-18

VRTĚL, M.-KUDLAČ, E.: Léčba syndromu ovariálních cyst u skotu aplikací HCG a kombinací HCG s progesteronem. Veterinářství, 26, 1976: 250-252 